\title{
The Impact of Group Size on Decision Effectiveness
}

\author{
Juliana Osmani \\ Ph.D, Management Department, Business Faculty, \\ University “A. Moisiu”, Durrës, Albania
}

\section{Abstract}

The relationship between organization and environment, based on the need to gather information and find resources, is increasingly characterized by a high level of uncertainty. Uncertainty means that managers do not have enough information and time to anticipate changes and make good decisions. More and more managers make decisions about new problems or situations. The level of risk increases, as well as the degree of complexity that the decision maker has to face. Under these conditions, organizations are moving towards the use of groups. The main purpose of the current research is to identify what are the most important benefits and limits of the group referring to its size, taking into analysis the banking institutions. For the current study is adopted the quantitative research and for the data collection is used the questionnaire. A total of 344 questionnaire are distributed. $80 \%$ of the participants agree that group size affects the quality of the decisions made and most of them prefer small groups. Also, most of them believe that within large groups are more conflicts, the relationships between members are more formal, the attention and individual commitment are lower than in small groups, the consensus is difficult, decisions can be made only through a voting process and there are no delays in decision-making, but coordination problems are not necessarily higher than within small groups.

Keywords: group decision-making, group size, group productivity, coordination, decision effectiveness

\section{Introduction}

When individual decision-making is compared to group decision-making, the advantages of the latter are numerous. It is thought that groups make better decisions than individuals, but we must said that groups make also bad decisions.

According to Cohen and Bailey (1997), effectiveness is a function of environmental factors, contextual factors, group processes and its psycho-social characteristics. Environmental factors refer to the characteristics of the industry in which the organization operates, such as the degree of uncertainty or turbulence. Contextual 
factors relate to the characteristics of the task, group and organization. Among the task variables we can mention autonomy and interdependence, while within group variables are the size, the demographic characteristics and the diversity. Organizational variables are rewards and supervision. Group processes refer primarily to communication, collaboration and conflict, while group psycho-social variables include norms, cohesion, mental models and affection.

If we analyze the above variables, we can easily distinguish that group's size has a significant impact on the effectiveness of the decisions made, although not directly. Thus, there are evidences to support that group size affects rewards and supervision, the type of communication and relationships between group members, conflict, cohesion and affection. However, we must admit that the issue of group effectiveness assessment is much more complex than we might think.

\section{Aim of the study and research questions}

The relationship between organization and environment, based on the need to gather information and find resources, is increasingly characterized by a high level of uncertainty. Uncertainty means that managers do not have enough information and time to anticipate changes and make good decisions. More and more managers make decisions about new problems or situations. The level of risk increases, as well as the degree of complexity that the decision maker has to face. Under these conditions, organizations are moving towards the use of groups.

If compared to individual decision-making, the advantages of group decision-making are numerous, but groups make bad decisions also. There are many studies that try to highlight the variables that influence group effectiveness, with the aim of helping the various business leaders and managers to improve the decisions made by the group. Undoubtedly, the performance of the group is influenced by a number of factors, some of which are under the control of the organization. One of these factors is the size of the group.

The main purpose of the current research is to identify what are the most important benefits and limits of the group referring to its size. Thus, in consistency with the main purpose, the research questions are formulated as follows:

1. How much are preferred large groups to make decisions?

2. What are the advantages of large groups compared to small groups?

3. What are the problematic aspects of large groups compared to small groups?

\section{Literature review}

The size is perhaps the most important variable of the group structure, because it directly influences group's ability to make a final decision. It should be noted that there is no consensus among researchers on the number of group members, but most of them argue that it is easier to reach consensus in groups of 5-7 members. Depending on the degree of complexity of the decision, the number of group members 
can increase to 12 , but if they are more, it is argued that we are dealing with an ineffective group (Kume, 2010).

Large groups often operate as an aggregate of two or more subgroups. In some cases, the size of the functional group which is represented by the number of members actively participating is smaller than the size of the nominal group (Baron et al., 1992). The size of the group depends on various factors, such as the nature of the situation for which it have to decide (Noorderhaven, 1995).

Within large groups, competitiveness is high. If we refer to the experiments of Tripletts (1898), competitive situations increase individual commitment. But on the other hand, Allport (1924) highlights that the presence of others stimulates a member to commit more and leads to better results only for simple tasks. The opposite is true for difficult tasks. Furthermore, in large groups some members may take passive positions, a phenomenon known as "social loafing" (Liden, Wayne, Jaworski and Bennett, 2004). Individuals often commit less when they have to achieve a goal by operating in a large group than when they operate alone (Latané, Williams and Harkins, 1979). This means that in large groups some members become unproductive. Thus, in large groups motivation may decrease even if this depends on how the situation is perceived. The more the decision is perceived as being of particular importance, the more involved the group members are. Another reason that can lead to social loafing is tasks' interdependence. It has been proven that more the individual perceives that his task is interdependent, more difficult becomes for him to feel personal achievement referring to his work. When perceptions about the interdependence of tasks are high, individuals believe that their efforts are indistinguishable from the efforts of other members of the group. Thus, they think that it would be better to minimize their commitment, since there is no possibility for personal thanks or gratitude.

On the other hand, larger is the group, more the cohesion decreases. Coordination problems (Steiner, 1972) and productivity blockages (Diehl and Stroebe, 1987, 1991) can also occur within these groups. Experiments have shown that there is an important correlation between the degree of cohesion and social loafing. If group members do not like each other or do not have a close relationship with each other, they are more prone to social loafing. Moreover, if group members have a highly developed sense of "we", they perceive social loafing as a behavior that should not be adopted. In fact, studies have shown that there is a negative correlation between cohesion and social loafing.

Difficulties in coordination may appear during problem-solving phase and also decision-making phase. Thus, coordination losses can arise in particular in the analysis phase, but also in the selection phase, because the exchange of information is crucial for the generation, evaluation and selection between alternative courses of action. One possible source for coordination losses is productivity blockage: only one member of the group can speak and others have to wait for their turn. 
Noorderhaven (1995) points out that small groups are more vulnerable because individual incompatibilities can paralyze decision-making, while large groups with more than 10 people tend to develop a more formal style of interaction, where individual differences can be covered more easily.

Within large groups are formed subgroups, which tend to deviate from the common objectives of the group and pursue their own interests. According to Scott (1987), within a group we can distinguish three types of subgroups. The first is the subgroup of the primary position, which is the epicenter of the group, because it constitutes the rules and guide the group towards the targets. The second subgroup is the subgroup with special status, composed by important members, which are supporters of the first subgroup, but they have the privilege to act independently of the primary position. The third is the subgroup without status, made up of members who have not influence on group decisions and that are often chosen to respect the predetermined size of the group. More subgroups are formed within a group, the greater is the risk of ineffective decisions.

Large groups must also be avoided because they damage the true interdependence and significant interactions between the members (Straus, Parker, Bruce and Dembosky, 2009). However, small groups fall more often in the use of the various biases and are more affected by the positivity towards their own group (Hewstone, Rubin and Willis, 2002).

Kreitner and Kinicki (2007) distinguish between two approaches: the mathematical approach and the approach of laboratory simulations. Mathematical models try to evaluate the optimal group size according to the desired results, such as the quality of decisions. According to these models it is not possible to establish the right size, which can vary from 3 to 13 members. There is no agreement on the size of the group even for the approach of laboratory simulations. Thus, Yetton and Bottger (1982) believe that the most effective groups are those of 4-5 members, while Laughlin, Hatch, Silver and Boh (2006) have concluded that for the decisions that require high intellect, the best groups are those of 3 members.

It should be noted that it is not always easy to determine the size of the group and to be sure that the number only is enough for good decisions, even when it is met as a condition. Referring to this, an important role is played by the personal perceptions on membership. Four types of group membership can be distinguished, as shown in Figure 1.

Psychological membership refers to the situation in which a member of the group feels attracted to the group and at the same time accepted by the other members. In the case of preferential membership, the individual feels attracted to the group, but finds it difficult to be accepted by others. In the marginal membership the situation is totally contrary. The individual is accepted by the other members of the group, but his attraction towards the group is low. Instead, in the alienative membership where 
both the attraction to the group and the acceptance by the other members are low, the individual can be considered outside the group.

\section{Figure 1. Four kinds of group membership}

Acceptance

High

Low

High

Psychological membership

Preferential membership

Attraction

Low

Marginal membership

Alternative membership

(Source: Noorderhaven, 1995, p.98)

According to what has been discussed above, to establish the size of the group, but also to choose the members, some questions must be answered: What is the individual propensity towards group decisions, is he an individualist or not? Furthermore, do the other members of the group agree on his participation and accept him as a member? This model demonstrates how acceptance and attraction are two important criteria to determine the size of a functional group.

Groups face problems and situations with different levels of complexity. Consequently, the different stages of the decision-making process require a different commitment. Decision-making process can be difficult for large groups, but can be successfully accomplished in groups of up to 12 people. The following table evaluates the effectiveness of the group according to its size.

Tabel 1. Group effectiveness and size

\begin{tabular}{|l|l|l|l|l|l|}
\hline & $\begin{array}{l}2-3 \\
\text { members }\end{array}$ & $\begin{array}{l}4-6 \\
\text { members }\end{array}$ & $\begin{array}{l}7-12 \\
\text { members }\end{array}$ & $\begin{array}{l}13-20 \\
\text { members }\end{array}$ & $\begin{array}{l}\text { More than } \\
20 \text { members }\end{array}$ \\
\hline Problem solution & Very low & Low & Normal & High & Very high \\
\hline $\begin{array}{l}\text { Speed of } \\
\text { judgement }\end{array}$ & High & Very high & Normal & Low & Low \\
\hline $\begin{array}{l}\text { Participation of } \\
\text { members }\end{array}$ & Very high & High & Normal & Low & Low \\
\hline Cohesion & Very high & High & Normal & Low & Low \\
\hline Consensus & Low & Low & Normal & Very high & Low \\
\hline Flexibility & Very high & High & Normal & Low & Low \\
\hline $\begin{array}{l}\text { Personal } \\
\text { productivity }\end{array}$ & Very low & Low & Normal & Low & Very low \\
\hline Group productivity & Very low & Low & Normal & Very high & Low \\
\hline
\end{tabular}

(Source: Kume, 2010, p.89) 
The size of the group affects objectives achievement and is related to the type of objectives and decisions (Kreitner and Kinicki, 2007). As the group becomes larger, the interaction between members decreases and relationships become less affective. Furthermore, large groups tend more towards political than analytical solutions. But within larger groups, the energy and technical resources increase. The information collected is greater and is possible to identify more courses of action. Also, within large groups there are more critical judgments and the decisions made are more acceptable.

\section{Research methodology}

For the current study was adopted the quantitative research and for the data collection was used the questionnaire. This tool was considered useful in gathering facts and knowledge, behaviours and attitudes, opinions, motivations and perceptions regarding group's size and its impact on group effectiveness. The questionnaire facilitates the collection of more information in less time.

The formulation of the questions is very important and in this regard it has been tried to be clear in the content and to choose the most suitable form. Thus, the questions made were closed, which facilitate a quantitative evaluation. The questionnaire was developed based on the Likert Scale 1-5. It represents a simple technique that records the intensity of the agreement of each interviewee at each proposed statement, instead of simply approving or refusing them. The questions were formulated carefully, keeping in mind the object of the research. This field is characterized by a high level of confidentiality. Therefore, the risk was that the respondents gave unrealistic answers.

For the current research is chosen the non-probability sampling technique, mainly in the form of purposive sampling. So, the units of analysis are chosen for participating to group decision-making or for having the necessary knowledge and information about it. In some cases was also used the information provided from important or privileged subjects in order to identify other participants, anyway trying to meet certain criteria established previously. So, in addition to purposive sampling it was also used the snowball technique.

The sample was also determined based on the geographical criteria. Thus, the current research was focused on the banking institutions and their branches in Tirana and Durrës as the two main cities of Albania. It was considered more convenient to distribute the questionnaires to managers because they can provide more precise and detailed information about groups' size and decision-making effectiveness, as participants and compilers of decision-making policies and procedures. The managers selected for the survey belong to strategic and departmental level.

Table 2: The distributions of participants by hierarchical level

\begin{tabular}{|l|l|l|l|l|}
\hline Position City & Tirana & Durrës & Total & $\%$ \\
\hline
\end{tabular}




\begin{tabular}{|l|l|l|l|l|}
\hline Strategic level & 96 & 24 & 120 & $35 \%$ \\
\hline Department level & 118 & 106 & 224 & $65 \%$ \\
\hline Total & 214 & 130 & 344 & \\
\hline$\%$ & $62 \%$ & $38 \%$ & & $100 \%$ \\
\hline
\end{tabular}

Table 3: The distributions of participants by years of experience

\begin{tabular}{|l|l|l|}
\hline Interval of years & No. & $\%$ \\
\hline $1-5$ years & 77 & $22 \%$ \\
\hline $6-10$ years & 54 & $16 \%$ \\
\hline $11-15$ years & 112 & $33 \%$ \\
\hline $16-20$ years & 86 & $25 \%$ \\
\hline More than 20 years & 15 & $4 \%$ \\
\hline Total & 344 & $100 \%$ \\
\hline
\end{tabular}

\section{Empirical findings}

Through the distribution of the questionnaires, we have tried to collect information about the impact of group size on its effectiveness, based on the participants' experiencies and perceptions. A total of 412 questionnaires were distributed and 344 collected, for a response rate of $83.5 \%$. Following, through tables and charts are summarized the data collected for each statement included in the questionnaire.

1: In the company where I work, groups are largely used for making decisions.

\section{Table 4. Number of responses for each scale (Statement 1)}

\begin{tabular}{|l|l|l|l|l|}
\hline $\begin{array}{l}\text { Strongly } \\
\text { disagree }\end{array}$ & Disagree & Neutral & Agree & Strongly agree \\
\hline 18 & 13 & 21 & 134 & 158 \\
\hline
\end{tabular}

Figure 2. Percentage of responses for each scale (Statement 1)

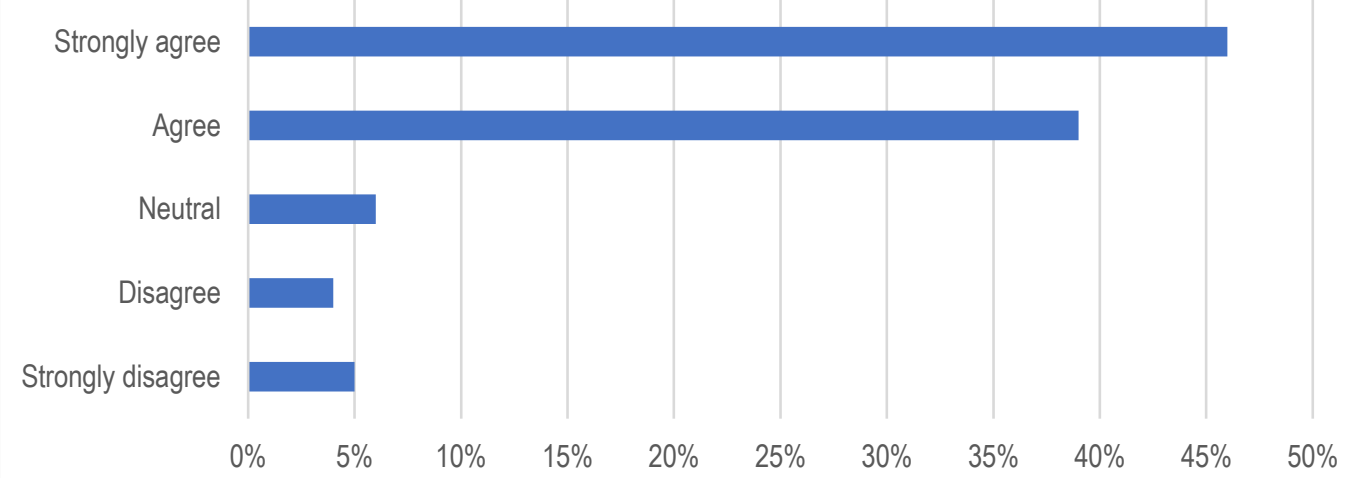

It was decided to take into analysis the banking sector because from the information collected informally prior to the current research, we were informed that almost all the decisions within the banking institutions are made by groups. As we can note 
from Figure 2, 85\% of the participants affirm that group decision-making processes are widely used within their organizations.

2: The number of group members affects the quality of the decisions made.

Table 5. Number of responses for each scale (Statement 2)

\begin{tabular}{|l|l|l|l|l|}
\hline $\begin{array}{l}\text { Strongly } \\
\text { disagree }\end{array}$ & Disagree & Neutral & Agree & Strongly agree \\
\hline 26 & 31 & 12 & 88 & 187 \\
\hline
\end{tabular}

Figure 3. Percentage of responses for each scale (Statement 2)

Statement 2

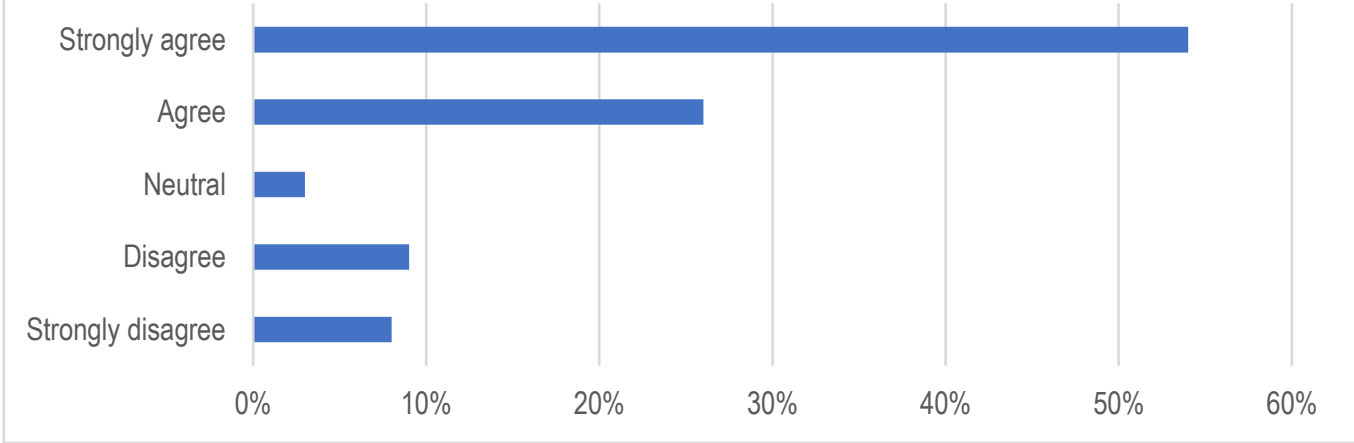

From Table 5 and Figure 3, we can easily notice that $80 \%$ of the participanmts agree that the number of group members affects the quality of the decisions made. This is in consistency with the discussion made previously in the literature review. There are many studies and researchers that consider the group size an important variable that impacts the quality of decisions. However, we must underline that the right group size is not a guarantee for good decisions.

3: I prefer large groups to make decisions.

Table 6. Number of responses for each scale (Statement 3)

\begin{tabular}{|l|l|l|l|l|}
\hline $\begin{array}{l}\text { Strongly } \\
\text { disagree }\end{array}$ & Disagree & Neutral & Agree & Strongly agree \\
\hline 62 & 129 & 34 & 47 & 72 \\
\hline
\end{tabular}

It is so much discussed on group size, if large groups are better than small groups, but there is not an accordance by the previous studies regarding this. The results of Table 6 and Figure 4 show that 55\% of the participants prefer small groups, 35\% of them prefer large groups, while $10 \%$ of the participants have not a preference.

With the other statements of the questionnaires, we have tried to understand what are the most important benefits and limits of large groups. However, we consider the 
current study as a starting point for future researches in order to understand better why large groups are and are not preferred.

\section{Figure 4. Percentage of responses for each scale (Statement 3)}

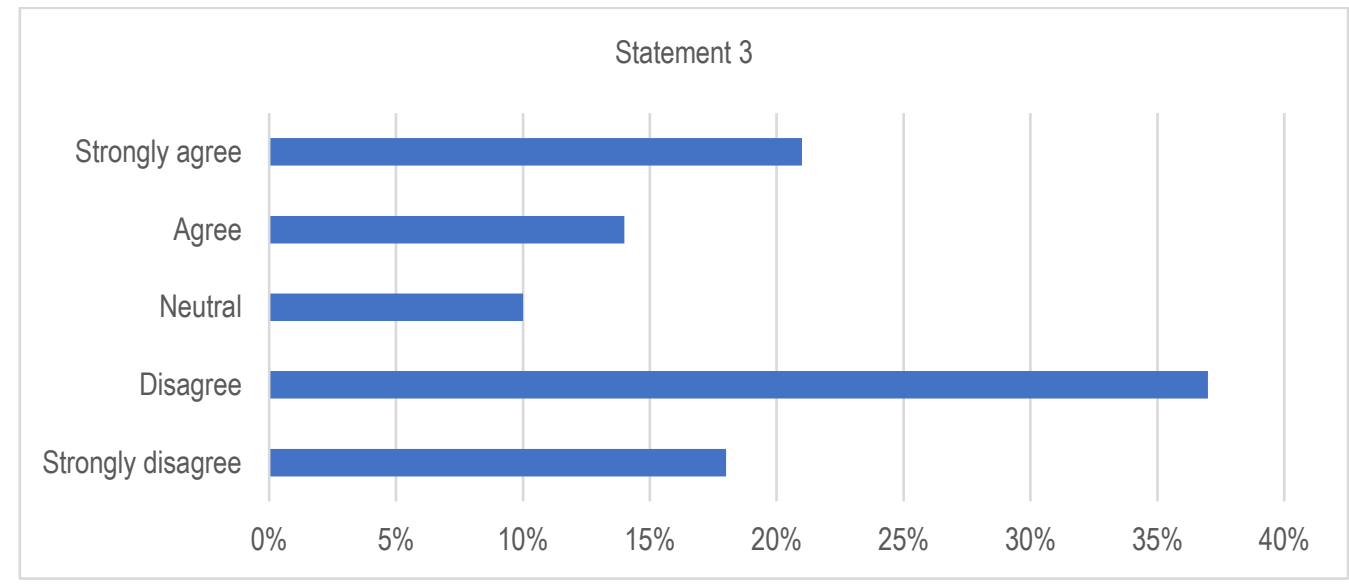

4: Within large groups, there are more conflicts.

Table 7. Number of responses for each scale (Statement 4)

\begin{tabular}{|l|l|l|l|l|}
\hline $\begin{array}{l}\text { Strongly } \\
\text { disagree }\end{array}$ & Disagree & Neutral & Agree & Strongly agree \\
\hline 45 & 77 & 8 & 105 & 109 \\
\hline
\end{tabular}

\section{Figure 5. Percentage of responses for each scale (Statement 4)}

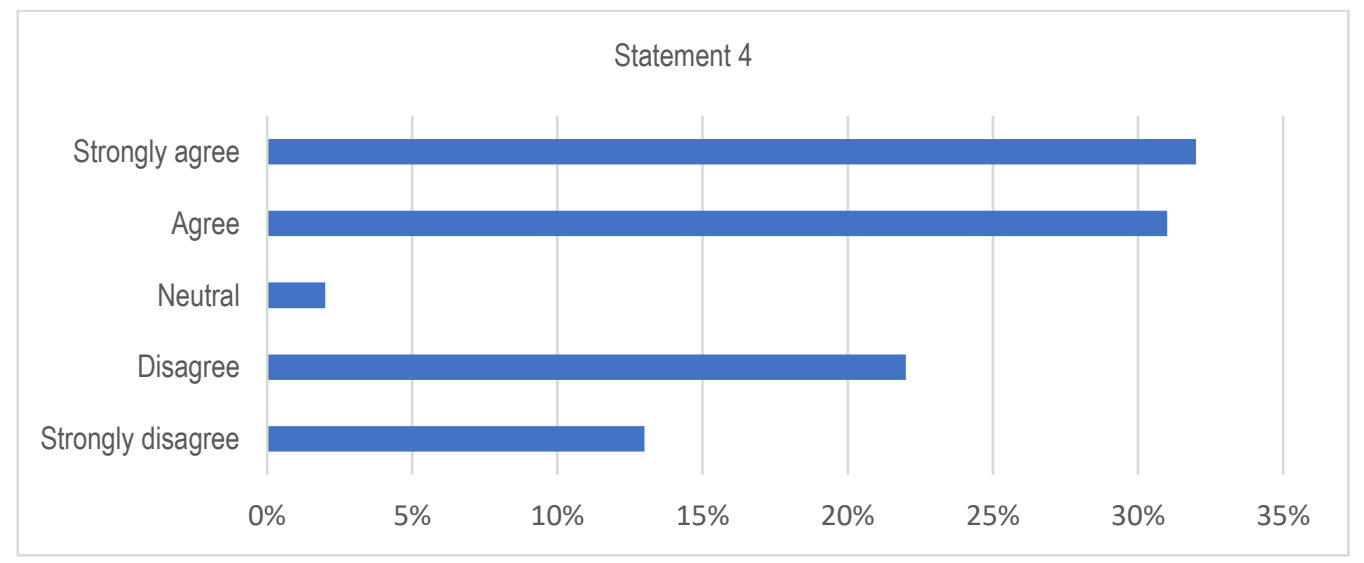

Previous researches have shown that for large groups conflicts are higher and cohesion is lower than for small groups. The results of the current study are in consistency with the previous studies. $63 \%$ of the participants of the current research agree that within large groups are more conflicts, while 35\% of them doesn't think so.

5: If the group is large, the relationships between members are more formal. 


\section{Table 8. Number of responses for each scale (Statement 5)}

\begin{tabular}{|l|l|l|l|l|}
\hline $\begin{array}{l}\text { Strongly } \\
\text { disagree }\end{array}$ & Disagree & Neutral & Agree & Strongly agree \\
\hline 37 & 58 & 17 & 101 & 131 \\
\hline
\end{tabular}

Figure 6. Percentage of responses for each scale (Statement 5)

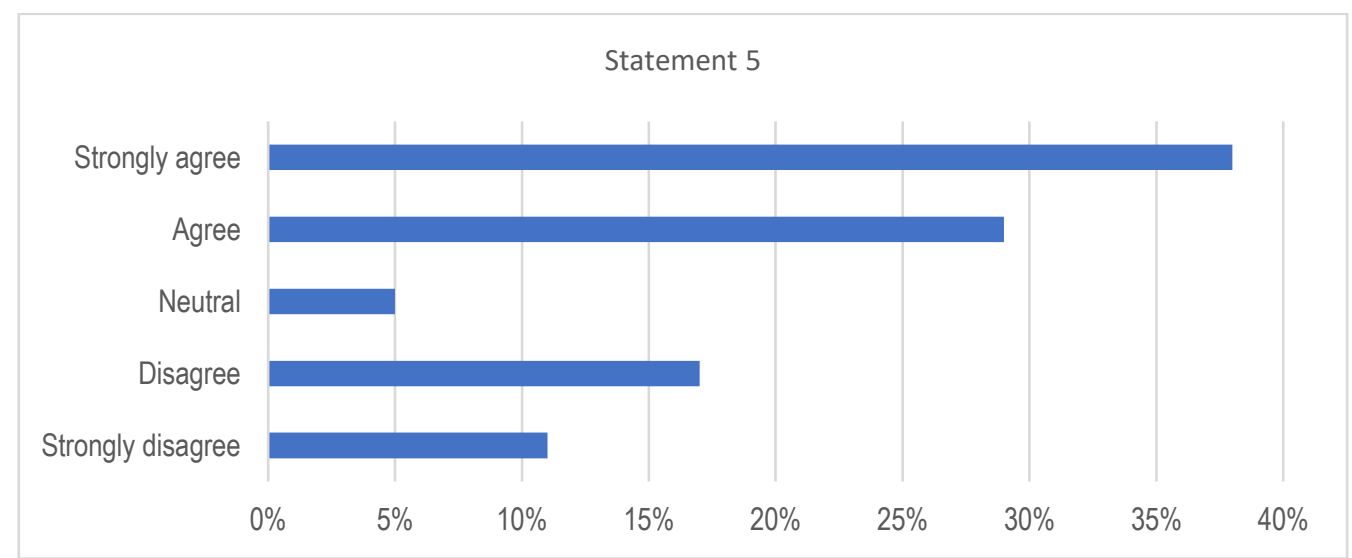

$67 \%$ of participants of the current research admit that the relationships between members of a large group are more formal. Also, this result is in consistency with the conclusions of previous studies.

6: In large groups, the attention and individual commitment are lower than in small groups.

\section{Table 9. Number of responses for each scale (Statement 6)}

\begin{tabular}{|l|l|l|l|l|}
\hline $\begin{array}{l}\text { Strongly } \\
\text { disagree }\end{array}$ & Disagree & Neutral & Agree & Strongly agree \\
\hline 89 & 147 & 7 & 32 & 69 \\
\hline
\end{tabular}

\section{Figure 7. Percentage of responses for each scale (Statement 6)}

\section{Statement 6}

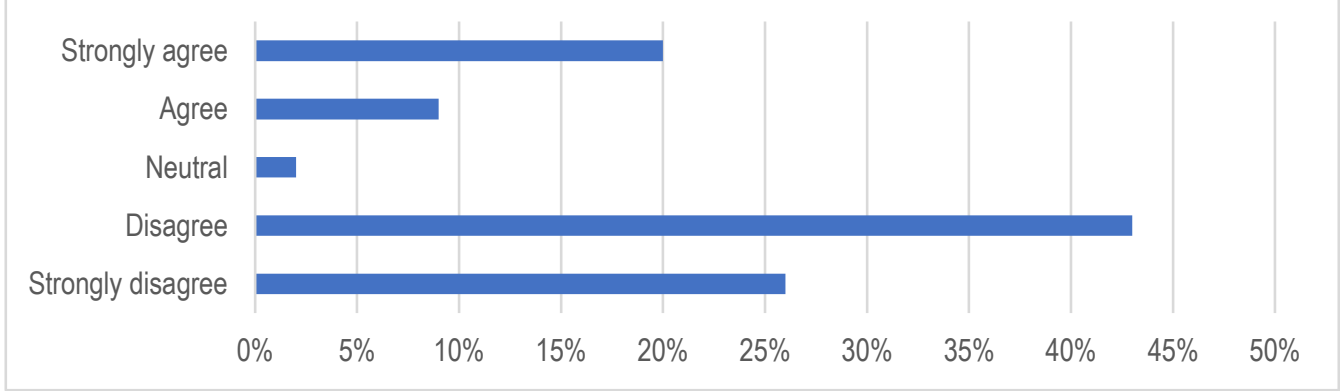


According to Liden et al. (2004), in large groups some members may take passive positions, a phenomenon known as "social loafing". Individuals often commit less when they have to achieve a goal by operating in a large group than when they operate alone. This means that in large groups some members become unproductive. $69 \%$ of the participants in the current research agree that within large groups, the attention and individual commitment are lower than in small groups. One more time, the results of the current research are in consistency with the previous studies.

7: In small groups, the consensus is easier than in large groups.

Table 10. Number of responses for each scale (Statement 7)

\begin{tabular}{|l|l|l|l|l|}
\hline $\begin{array}{l}\text { Strongly } \\
\text { disagree }\end{array}$ & Disagree & Neutral & Agree & Strongly agree \\
\hline 22 & 54 & 0 & 94 & 174 \\
\hline
\end{tabular}

Figure 8. Percentage of responses for each scale (Statement 7)

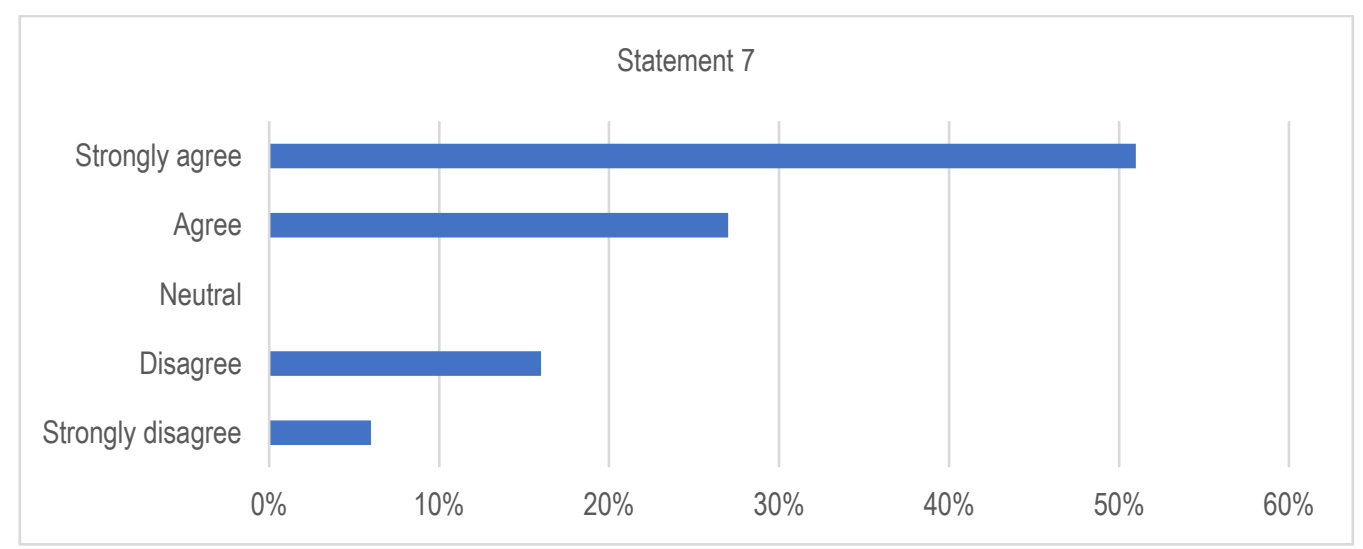

There are evidences that take into analysis the impact of group size on consensus achievement. It is believed that in small groups the consensus is easier than in large groups. $78 \%$ of the participants of the current research agree with this conclusion.

8: In large groups, decisions can be made only through a voting process.

\section{Table 11.Number of responses for each scale (Statement 8)}

\begin{tabular}{|l|l|l|l|l|}
\hline $\begin{array}{l}\text { Strongly } \\
\text { disagree }\end{array}$ & Disagree & Neutral & Agree & Strongly agree \\
\hline 59 & 73 & 0 & 113 & 99 \\
\hline
\end{tabular}




\section{Figure 9. Percentage of responses for each scale (Statement 8)}

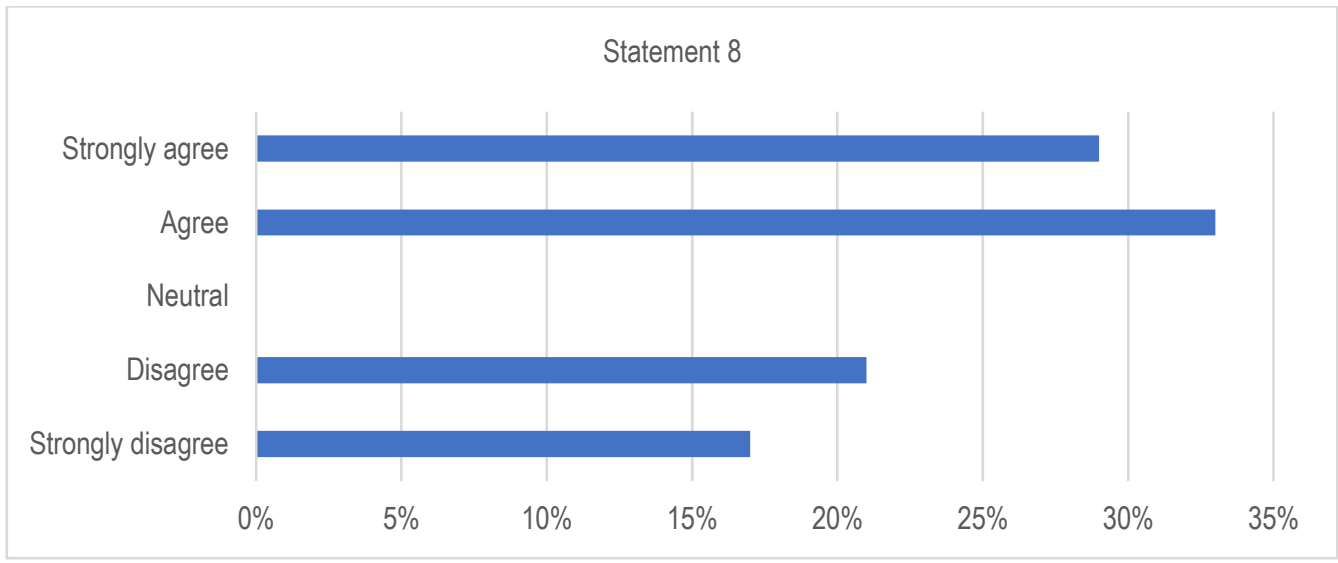

$62 \%$ of them believe that in large groups decisions can be made only through a voting process. So, there will be always a minority that will have to submit to the majority.

9: In large groups, there are often delays in decision-making.

\section{Table 12. Number of responses for each scale (Statement 9)}

\begin{tabular}{|l|l|l|l|l|}
\hline $\begin{array}{l}\text { Strongly } \\
\text { disagree }\end{array}$ & Disagree & Neutral & Agree & Strongly agree \\
\hline 86 & 130 & 24 & 69 & 35 \\
\hline
\end{tabular}

\section{Figure 10. Percentage of responses for each scale (Statement 9)}

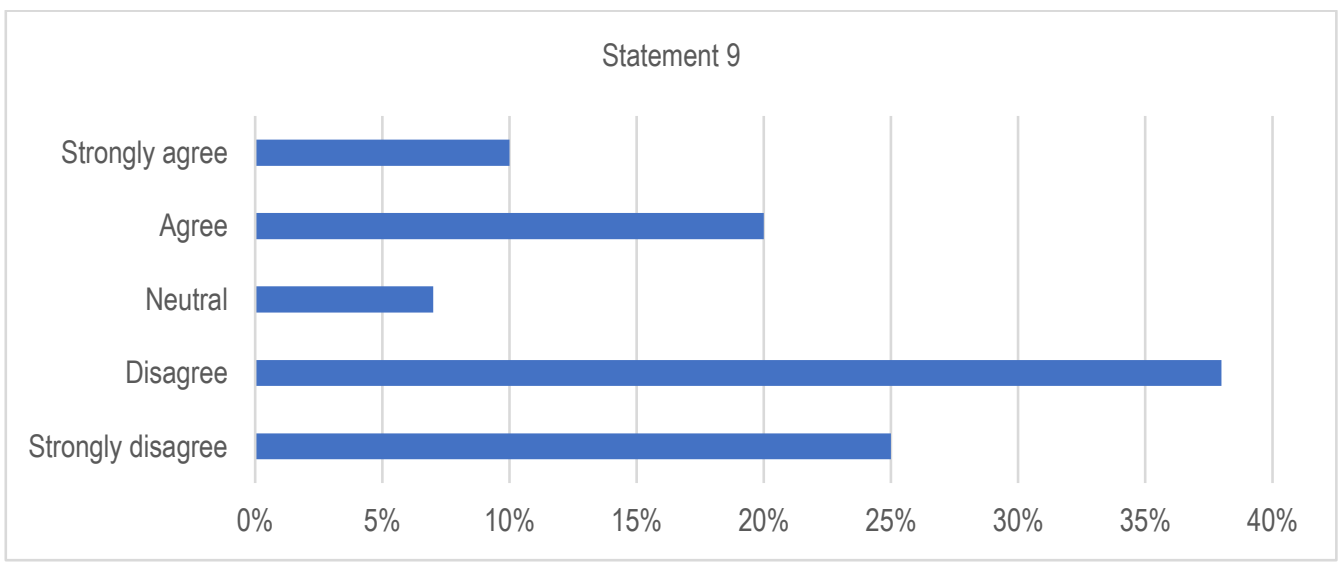

$63 \%$ of participants do not believe that in case of large groups, there are often delays in decision-making. This conclusion is in consistency with the previous one. A voting process shortens the time required for making a final decision.

10: For small groups, group operation and coordination are easier. 


\section{Table 13. Number of responses for each scale (Statement 10)}

\begin{tabular}{|l|l|l|l|l|}
\hline $\begin{array}{l}\text { Strongly } \\
\text { disagree }\end{array}$ & Disagree & Neutral & Agree & Strongly agree \\
\hline 32 & 147 & 14 & 57 & 94 \\
\hline
\end{tabular}

Figure 11. Percentage of responses for each scale (Statement 10)

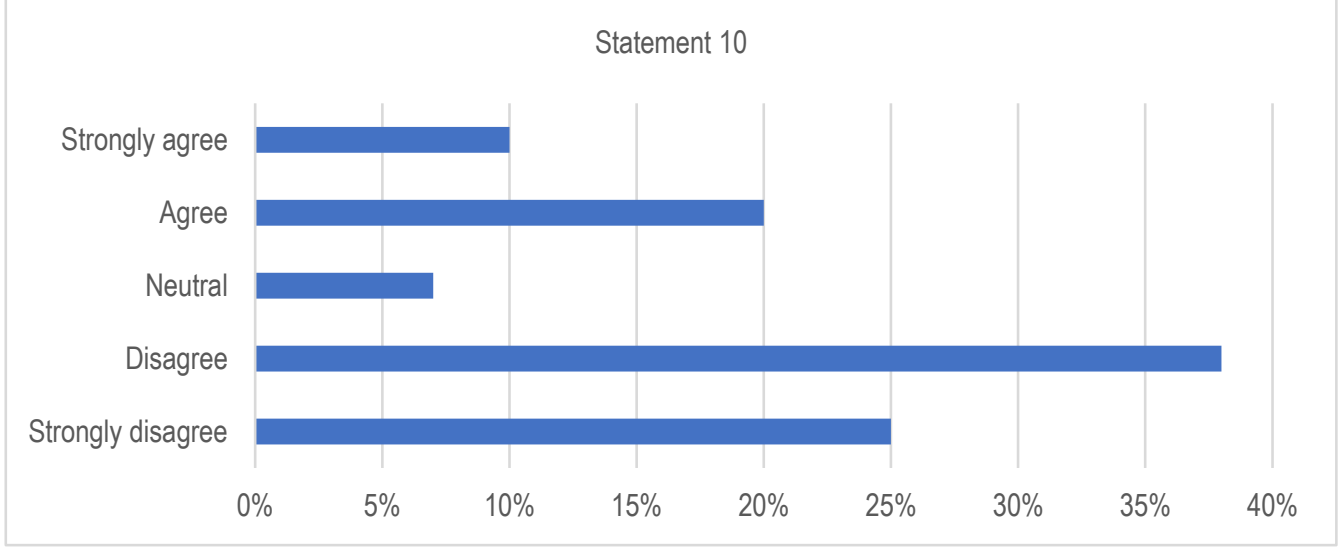

According to Steiner (1972), large groups are characterized by coordination problems. $44 \%$ of the participants believe that for small groups, group operation and coordination are easier. So, coordination problems does not depend only on group size.

\section{Conclusion}

The main purpose of the current research was to identify what are the most important benefits and limits of the group referring to its size. Thus, in consistency with the main purpose, the research questions were formulated in order to understand how much are preferred large groups to make decisions and what are the advantages and problematic aspects of large groups compared to small groups. It was decided to take into analysis the banking sector because from the information collected informally prior to the current research, we were informed that almost all the decisions within the banking institutions are made by groups, a fact which is also confirmed by the present research. Thus, $85 \%$ of the participants affirm that group decision-making processes are widely used within their organizations. But what think the participants about the importance of group size? $80 \%$ of them agree that the number of group members affects the quality of the decisions made.

It is so much discussed on group size, if large groups are better than small groups, but there is not an accordance by the previous studies regarding this. The results of the current research show that $55 \%$ of the participants prefer small groups, $35 \%$ of them prefer large groups, while $10 \%$ of the participants have not a preference.

But what are the benefits and limits of group decision-making according to its size? Previous researches have shown that for large groups conflicts are higher and 
cohesion is lower than for small groups. $63 \%$ of the participants of the current research agree that within large groups are more conflicts, while $35 \%$ of them doesn't think so. On the other hand, $67 \%$ of them admit that the relationships between members of a large group are more formal. According to Liden et al. (2004), in large groups some members may take passive positions, a phenomenon known as "social loafing". Individuals often commit less when they have to achieve a goal by operating in a large group than when they operate alone. This means that in large groups some members become unproductive. $69 \%$ of the participants in the current research agree that within large groups, the attention and individual commitment are lower than in small groups. There are evidences that take into analysis the impact of group size on consensus achievement. It is believed that in small groups the consensus is easier than in large groups. $78 \%$ of the participants of the current research agree with this conclusion. Furthermore, $62 \%$ of them believe that in large groups decisions can be made only through a voting process. So, there will be always a minority that will have to submit to the majority. $63 \%$ of participants do not believe that in case of large groups, there are often delays in decision-making. This conclusion is in consistency with the previous one. A voting process shortens the time required for making a final decision. According to Steiner (1972), large groups are characterized by coordination problems. $44 \%$ of the participants believe that for small groups, group operation and coordination are easier. So, coordination problems does not depend only on group size.

\section{Recommendations}

The group is a study object in many domains. Due to the change of contextual factors, but not only, as the more dynamic environment, the increasing level of problems' complexity, the transition from vertical structures to more flexible structures, etc., organizations are increasingly using groups to make decisions. However, the use of the group does not absolutely guarantee good decisions. A very important factor that affects the effectiveness of group decisions is its size. There is no consensus among researchers on the optimal size of the group, but there are enough studies that show that large groups of more than 12 members bring more problems than benefits.

At the end of the present research, we would recommend:

- The avoidance of large groups, in order to minimize conflicts and delays in decision-making;

- A careful selection of group leader, with good organization and coordination skills;

- A careful selection of group members according to their problem knowledge and skills;

- The creation of a positive climate and spirit of cooperation within the group; 
- Conditions for each member of the group to have the opportunity to contribute to the decision-making process.

\section{References}

[1] Allport F.H. (1924), Social psychology, Boston: Houghton Mifflin Company

[2] Baron R., Kerr N., Miller N. (1992), Group decision-making. In Noorderhaven N.G. (1995), op. cit.

[3] Cohen S.G., Bailey D.E. (1997), What makes teams work: Group effectiveness research from the shop floor to the executive suite, Journal of Management, Vol. 23, No. 3, pp. 239-290

[4] Diehl M., Stroebe W. (1987), Productivity loss in brainstorming groups: Toward the solution of a riddle, Journal of Personality and Social Psychology, Vol. 53, No. 3, pp. 497-509

[5] Diehl M., Stroebe W. (1991), Productivity loss in idea-generating groups: Tracking down the blocking effect, Journal of Personality and Social Psychology, Vol. 61, pp. 392-403

[6] Hewstone M., Rubin M., Willis H. (2002), Intergroup bias, Annual Review of Psychology, Vol. 53, pp. 575-604

[7] Kreitner R., Kinicki A. (2007), Organizational behavior, $7^{\text {th }}$ Edition, New York: McGraw-Hill/Irwin

[8] Kume V. (2010), Marrja e vendimeve manaxheriale, Botimi i 4-t, Tiranë: Pegi

[9] Latané B., Williams K., Harkins S. (1979), Many hands make light the work: The causes and consequences of social loafing, Journal of Personality and Social Psychology, Vol. 37, No. 6, pp. 822-832

[10] Laughlin P.R., Hatch E.C., Silver J.S., Boh L. (2006), Groups perform better than the best individuals on letters-to-numbers problems: Effects of group size, Journal of Personality and Social Psychology, Vol. 90, No. 4, pp. 644-651

[11] Liden R.C., Wayne S.J., Jaworski R.A., Bennett N. (2004), Social loafing: A field investigation, Journal of Management, Vol. 30, No. 2, pp. 285-304

[12] Noorderhaven N.G. (1995), Strategic decision making, Wokingham: AddisonWesley Longman

[13] Scott W.R. (1987), Group theory, New York: Dover Publications Inc.

[14] Steiner I.D. (1972), Group process and productivity, New York: Academic Press

[15] Straus S.G., Parker A.M., Bruce J.B., Dembosky J.W. (2009), The Group Matters: A review of the effects of group interaction on processes and outcomes in 
analytic teams, Project Memorandum: PM-2392-1-USCA. RAND Corporation Working Paper, National Security Research Division, Washington, DC

[16] Triplett N. (1898), The dynamogenic factors in pacemaking and competition, American Journal of Psychology, Vol. 9, No. 4, pp. 507-533

[17] Yetton P.W., Bottger P.M. (1982), Individual versus group problem solving: An empirical test of a best member strategy, Organizational Behavior and Human Performance, Vol. 29, pp. 307-321 